\title{
Glutamine metabolism and the unfolded protein response in MYC-driven breast cancer
}

\author{
Ayesha Shajahan-Haq ${ }^{*}$, Katherine Cook, Jessica Schwartz-Roberts, Ahreej Eltayeb, Diane Demas, Anni Warri, \\ Leena Hilakivi-Clarke, Robert Clarke \\ From Metabolism, Diet and Disease 2014: Cancer and metabolism \\ Washington DC, USA. 28-30 May 2014
}

Antiestrogens are used to treat estrogen receptor positive $(\mathrm{ER}+)$ breast tumors that constitute $70 \%$ of all breast cancer cases. Unfortunately, acquired resistance to antiestrogen therapy remains a critical clinical obstacle. Here we show that human breast cancer cells and rat mammary tumors that have acquired resistance to antiestrogens express increased levels of MYC, a major regulator of both glutamine and glucose. Glutamine metabolism and glucose uptake were elevated in ER+ antiestrogen resistant cells (LCC9) compared with sensitive cells (LCC1). Inhibition of MYC, with siRNA or small molecule inhibitor, reduced cell viability and uptake of both glutamine and glucose in resistant cells. In resistant cells, MYC expression controlled protein levels of glutamine, glutamate and glucose transporters as well as GLUL and GLS, two enzymes that promote glutamate-glutamine inter-conversion. Increased MYC function in resistant cells correlated with increased cellular sensitivity to deprivation of, and also inhibitors of, both glutamine and glucose. While apoptosis eliminated all resistant cells in glucose-only conditions beyond $72 \mathrm{~h}$, in glutamine-only conditions, the unfolded protein response (UPR) via GRP78-IRE1 $\alpha$ and activating JNK and increased CHOP, induced apoptosis in majority of the cells but promoted survival in some. The antiestrogen faslodex (FAS; ICI 182,780 ) significantly reduced glucose uptake in antiestrogen resistant cells compared with sensitive cells. Thus, our findings reveal unique roles for MYC in promoting metabolic flexibility in and promoting survival in antiestrogen resistant breast cancer cells via the UPR. Targeting glutamine and glucose metabolism pathways, therefore, may provide novel strategies in treating endocrine resistant breast cancers.

\footnotetext{
Department of Oncology, Lombardi Comprehensive Cancer Center, Georgetown University Medical Center, Georgetown, Washington, DC, USA
}

Published: 28 May 2014

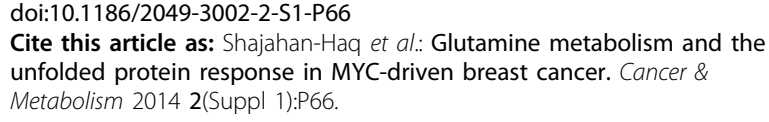

Submit your next manuscript to BioMed Central and take full advantage of:

- Convenient online submission

- Thorough peer review

- No space constraints or color figure charges

- Immediate publication on acceptance

- Inclusion in PubMed, CAS, Scopus and Google Scholar

- Research which is freely available for redistribution 